Diabetologia (1995) 38 [Suppl 1]: I-V

\title{
Minutes of the 30th General Assembly of the European Association for the Study of Diabetes
}

\section{Held in Hall 1 in the Messe-Kongress-Center Süd, Düsseldorf, Germany, on Friday, September 30, 1994 from 17.15-18.30}

$\begin{array}{lll}\text { Present: } & \text { Drs. KGMM Alberti } & \begin{array}{l}\text { (President, } \\ \text { in the Chair) } \\ \text { (Hon. Secretary) } \\ \text { A de Leiva }\end{array} \\ \text { E Ferrannini } & \begin{array}{l}\text { (Editor-in-Chief, } \\ \text { Diabetologia) }\end{array} \\ \text { JCC Nunes-Correa } & \text { (Hon. Treasurer) }\end{array}$

and 107 members

After having welcomed all members, the President reported on the deaths of three EASD members, Drs. H.Sauer, J.C.Sodoyez and P.Stolba, the latter one had been a member of the Local Organising Committee 1992 and of this year's Abstract Selection Committee. The General Assembly stood in silence in their memory.

\section{Minutes, 29th General Assembly 1993}

The President asked the General Assembly for approval of the Minutes of the 29th General Assembly, Istanbul, 1993, before the minutes were signed by himself and Dr. de Leiva as a correct record.

\section{Reports}

a) President: Dr. Alberti started his report by thanking Drs. N.Bagriacik, H. Ilkova and Ms S.Bagriacik for the remarkable Annual Meeting they had organized in 1993. He expressed his thanks to Hoechst $A G$, Gemany, for sponsoring the Minkowski Prize, which had this year been awarded to Dr. T.Mandrup-Poulsen from Denmark. The Camillo Golgi Lecture, this year delivered by Dr. J.E. Tooke from United Kingdom, and the Castelli Pedroli Prize, were sponsored by the family of the late Maria Castelli Pedroli. Thanks were expressed to Eli Lilly who had sponsored the 3rd Eli Lilly/ EASD Research Fellowship which had been awarded to A. Sjöholm from Sweden and to Hoechst, France, (Laboratoires Paul Neumann) who had sponsored the Claude Bernard Lecturer 1994; Dr. G. Reaven will give his lecture on the last day of the Annual Meeting. The President thanked all Supporting and Associate Members for their continued support and especially Eli Lilly for their sponsorship towards the EASD Solidarity Fund and Novo Nordisk for their continued support of the EASD Travel Grants.

Dr. Alberti reported on the new EASD activities, e.g. the Meet-the-Expert Sessions, introduced at this EASD Meeting and the 2nd Scientist Training Course which will be held in May 1995. He also announced a Training Course for Nurses which is planned for the end of 1995 . Reporting on new approaches, Dr. Alberti informed the General Assembly of a new Travel Fellowship which will be announced in the EASD News Section in December 1994. Four of the eight fellowships will be sponsored by Bayer $A G$, the other half is paid by the EASD. Another new approach will be the 'Oxford Course', later in 1995 which is jointly organized by the EASD and JDFI. This course should bring together senior and junior members and is a result of new contacts with the JDFI. Dr. Alberti explained that these new activities represent the recent approaches of the EASD to promote more intensively diabetes research and also to put more effort into the study of diabetes.

Then the President informed the General Assembly that the Claude-Bernard-Committee had met in September 1994 and unanimously decided to award Dr. M.Berger from Düsseldorf as Claude Bernard Lecturer 1995.

As a last matter Dr. Alberti reported that the Executive Committee Members had decided to host the EASD Annual Meeting in Jerusalem in the year 2000 . Applications to organize the Annual Meeting in the year 2001 are welcome, an announcement will be printed in the EASD News Section in December 1994.

b) Honorary Treasurer: Dr. J.Nunes-Correa reported that the EASD accounts remained in a healthy condition in the year 1993. The number of members had furthermore increased and with it the income on membership fees. The amount of donations received was only slightly above the figure of last year. The largest income item was the surplus received from Annual Meetings which included a second payment from Prague $(£ 343000)$ and the surplus from the Istanbul Meeting $(£ 262000)$. Due to high assets bank interest increased over the year. On the expenditure side, the figure of salaries rose due to the employment of an additional part-time secretary. Nevertheless, it had been necessary to have extra office help during the time the abstracts were received and also for enter- 
ing the Provisional Programme into the computer. Rent of the EASD office had increased with a new two-year contract. Office costs rose as a new computer, printer and software had to be bought. As the EASD had paid for invited speakers' tickets, the amount spent on travel expenses was higher compared to previous year. Bank charges increased proportionally with the larger amount of membership fees. Expenses related to annual meetings reflected repeated site visits which had been necessary and also the fact that the Programme Committee had been increased by two members. This item also included free loans which were given to the organizers of the Annual Meetings for the years 1993, 1994 and 1995. More money was spent on Travel and Stayment grants as it had been necessary to cover not only registration and hotel expenses for East European members but also to pay for their airfares.

Dr. Nunes-Correa explained that for 1994 Travel and Stayment Grants had only been granted to presenting authors who had a paper accepted.

The figure for Prizes/Awards had remained unchanged compared to 1992. The higher figure from 1993 is due to a 1992 Albert Renold Fellowship which was only paid in 1993. As in previous years, a donation was given to the host country of last year's meeting. This time to the Czech Diabetes Association. Diabetologia subscriptions paid to Springer-Verlag was the largest single item of expenditure. The amount, totalling over $£ 200000$ approached ca. $80 \%$ of the income on membership fees. Dr. Nunes-Correa pointed out that the remaining $20 \%$ is not sufficient to cover salaries of the EASD staff. This shows how much the Association depends on the surplus of the Annual Meeting. This fact should always be kept in mind when thinking about e.g. the year 1997 when no EASD Meeting will be held. In addition, it should also be considered that more money will be spent on the journal due to the increased number of pages and membership fees have not been increased. Another expenditure item which had considerably increased was the payment to the Editorial office which was expected to be higher compared to last year due to transferring the office from Uppsala to Pisa. Expenses of the Postgraduate Education Sub-Committee did not differ to the figure of previous year.

Ending his report, Dr. Nunes-Correa informed the General Assembly that $86 \%$ of the financial assets of the EASD were held in the UK, $10 \%$ in Germany and only $4 \%$ in Switzerland. Most of the money was kept on reserve or fixed accounts.

The President thanked the Honorary Treasurer for his report and asked the Honorary Auditors for their statements. Dr. H.M.J. Krans who had checked the accounts at the EASD office and Dr. G. Schernthaner confirmed correctness of the accounts to the General Assembly.

c) Honorary Secretary: Dr. A. de Leiva started his report by informing the General Assembly that 4,244 members were recorded at the EASD on 31 December 1993, including 458 members who were supported by the Solidarity Fund, 10 Supporting and 4 Associate Members and 9 Honorary Members.

This year, the EASD had received 1,242 abstracts from 56 different countries. Changes regarding the format of the abstract (limit of 30 lines, type size not smaller than 10 pitch) had been successfully introduced this year. Abstracts raising ethical or statistical issues could have been marked on the abstract scoring sheet and had been discussed by the members of the Programme Committee. As in 1993 the Abstract Selection Committee consisted of 20 members of which 8 members finalized the scientific programme. At the Programme Committee Meeting a total of 837 abstracts were accepted (67\%, versus $59 \%$ in 1993), $323(39 \%)$ as oral presentations and 514 $(61 \%)$ as posters.
Dr. de Leiva reported that this year four State of the Art Lectures and four State of the Art Symposia were held. Two Symposia were sponsored by Hoechst AG and Novo Nordisk, whereas the other two were co-sponsored by Eli Lilly and JDFI. The programme also included a Local Lecture and for the first time eleven parallel 'Meet the Expert Sessions' on two evenings. A feed-back analyses showed that $95 \%$ of the participants support to continue these sessions.

Reporting on EASD Prizes and Fellowships, the Honorary Secretary informed the audience that Dr. L. Juntti-Bergren had been awarded the Albert Renold Fellowship. The 1994 Eli Lilly/EASD Research Fellowship was given to Dr. A.Sjöholm. This year, the Castelli Pedroli Prize and the Camillo Golgi Lecture 1994 had been awarded to Dr. J.E. Tooke, the 1994 Minkowski Prize had been awarded to Dr. T. Mandrup-Poulsen.

A total of 100 Travel Grant applications were accepted in 1994 , amounting to $£ 33227$. In addition, 14 Stayment Grants were provided to presenting authors coming from countries facing economical problems. In connection with these grants, a total of $£ 7170$ was spent on registration, accommodation and spending money.

Dr. de Leiva reported on the site visit to Stockhom in June 1994. The Congress Center provides ideal facilities and was seen 'in action' as an international event was being held.

The EASD News Section, the Honorary Secretary explained, had been operating since January, 1992. Study Groups take advantage of these pages by announcing their meetings and they also provide the EASD with brief reports. In addition information on the EASD Annual Meeting, announcements on Courses, Prizes, Fellowships and future meetings was printed. Beside the Prize Winners the new Council Members had also been introduced to the membership.

As a last matter Dr. de Leiva reported on the position of Diabetes at the Fourth Research Programme of the European Union. Dr. de Leiva informed the General Assembly that an approach to the General Director of Science, Research and Development, the Director of Biotechnology and Life Sciences and to all national CREAST Committee members was undertaken, urging them to suggest to the administrators of the Fourth Programme to recognize diabetes mellitus as a major health problem in order to receive proper funding for diabetes research.

At the end of his report Dr. de Leiva thanked all EASD officers, the Executive Director and the staff from the EASD Secretariat for their support and co-operation. He also thanked the members of the Abstract Selection and Final Programme Committee and all speakers and chairpersons. Then Dr. de Leiva announced that Dr. U. Eriksson will now share the position of Honorary Secretary with him for the period of one year, before completely taking over after the EASD Meeting in 1995.

The President thanked Dr. de Leiva for his report. In relation to Diabetes awareness within the EU it was suggested that a closer co-operation with the IDF could be useful. Criticism regarding the State of the Art Symposia was received. The complaining member was asked to provide the comments in writing. When no further questions or comments were received Dr. Alberti asked the Editor-in-Chief to present his report.

d) Editor-in-Chief, Diabetologia: Dr. Ferrannini began his first report to the General Assembly by stating that the Editorial Office had now been operating in Pisa for 11 months. The office had been fully equipped and the transfer of all materials had been finalized. Since September 1994 the staff at the office consists of 2 full time positions, one part-time editorial help and an additional secretary working only $15 \%$. 
Then Dr. Ferrannini informed the audience that in addition to the Abstract volume a supplementary issue to Diabetologia based on the Minkowski Graduates' Symposium held in 1993 had been published.

Providing some statistics the Editor-in-Chief explained that in 1993 the total number of manuscripts received was 631, a $22 \%$ increase to 1992. Until August 31st, 1994, 475 manuscripts had been received, projecting a number of 713 at the end of 1994 which would lead to a further $13 \%$ increase. Geographically, most manuscripts were received from UK and USA, directly followed by Japan. Contributions from Germany, Denmark, Finland and Sweden remained stable while those from Italy, France and Spain had sharply risen. The acceptance rate had dropped from $36 \%$ in 1992 to $29 \%$ in 1993 and is estimated at $24 \%$ for 1994 . The increase of 300 pages is expected to raise the rate back to $34 \%$. The acceptance rate for rapid communications was $32 \%$ in 1993 and is projected at $27 \%$ in 1994.

Continuing his report, Dr. Ferrannini informed the General Assembly that eight review articles were published in 1993 and a total of six will be published in 1994. The number of 'For Debate' papers will increase from six in 1993 to seven or eight in 1994. The average number of days for Associate Editors' reports and decisions had remained unchanged at about 8 weeks each, while Springer had taken longer for publication (120 days in 1993 vs 100 days in 1992). The overall time for publication was with 7.7 months in 1993 slightly longer than in 1992.

Dr. Alberti thanked Dr. Ferrannini for his report. A member asked the Editor-in-Chief if statements of Study Groups could be published. It was answered that review articles would be appreciated as the number of pages in the journal is limited. Study Group reports, rules and regulations could be submitted for inclusion into the EASD News Section.

The number of referees in relation to the proceeding time was discussed. Dr. Ferrannini explained the new procedure he had introduced when taking over the position of Editor-inChief. He invited all members to forward names of possible referees to him so that he can enter them into their computer system in order to spread the papers for review more equally.

Dr. Alberti thanked Dr. Ferrannini for his report and the successful take-over of the Editorial Office from Uppsala to Pisa.

\section{Elections}

a) President 1995-1998."The President informed the General Assembly of the Council's election of Dr. M.Berger (Germany) as his successor.

b) Honorary Treasurer 1994-1995. In order to avoid simultaneous retirement of two Executive Committee Members, the President informed the General Assembly that the Council Members had unanimously agreed to extend the Honorary Treasurer's term of office by one more year.

c) Council Members 1995-1998. Dr. Alberti announced the nominations for Council Membership: Drs. M.Benroubi (Greece), R.W.Bilous (United Kingdom), P.Halban (Switzerland) and H. Yki-Järvinen (Finland) who were unanimously approved by the General Assembly.

The President explained that nominations for these positions for the term 1996-1999 are welcome to be received at the EASD Secretariat. A call for nominations will be printed in the December 1994 issue of Diabetologia and all nominations received will be forwarded to the Executive Committee Members who will meet in April 1995.

Dr. Alberti informed the General Assembly of the replacement of the Honorary Auditors for the years 1995-1998. Drs. P.-J.Guillausseau (France) and D. Pipeleers (Belgium) will replace Drs. H.M.J. Krans and G. Schernthaner who the President thanked for their help and assistance over the past years.

\section{Postgraduate education subcommittee}

Dr. M. Berger summarized the activities of the PGESC's Action Plan 1992-1994 by reporting on a one-day course for Turkish physicians which was held in Istanbul after the EASD Meeting. The course was co-organized by the PGESC and the Diabetes Education Study Group and included plenary lectures and workshops in small groups. Approximately 300 delegates had attended this course.

According to the tradition of the PGESC, two Study Groups presentations were suggested to the local organizer in Istanbul. The European Study Group on Diabetic Eye Complications and the Study Group Diabetes Care Optimization Through Information Technology (DOIT) held their presentations after the EASD Meeting. Due to the weak reputation, it was decided by the Executive Committee to hold these presentations before the EASD Meeting which will also avoid overlapping with other symposia. In addition, this year the announcements had been made more visible in the Final Programme and the presentations of the Nutrition and the Neuropathy Study Group were held in two large halls.

Dr. Berger explained to the EASD members that no PGESC Course will be held after the 30th EASD Annual Meeting as a three-day course had taken place in Mettmann, Germany in January 1994, which was co-sponsored by the German Diabetes Association. 120 physicians from Germanspeaking countries plus ten invited physicians from Hungary, Czech Republic and Rumania attended the course which was divided into workshop groups, lectures and discussions.

Reporting on future courses, the PGESC Chairman informed about the active involvement in a course taking place in Tbilisi, Georgia, from 19-21 October 1994. This course is based on the IDF/WHO Twinning Programme between the Israel and Georgian Diabetes Associations. During the last week of October, a four-day postgraduate course is planned for diabetologists, physicians and allied health care personnel in Skopje, Macedonia. This course is co-organized with WHOEurope and will be combined with a one-week programme of site visits and postgraduate activities by a faculty of four diabetologists to all five diabetes care centers of the country. The last PGESC course under Dr. Berger's chairmanship will be held in Hungary in December 1994 for approximately 120 Hungarian General Practitioners. Starting from January 1995 until 1998, Dr. A. Boulton (UK) will be Chairman of the PGESC and Dr. J.Skrha (CZ) will be in the position of Honorary Secretary of the PGESC.

No questions or comments followed this report. Dr. Alberti expressed the Association's thanks to Drs. Berger and Fövenyi for their tremendous effort which had led into valuable results.

\section{Study groups}

Dr. Alberti reported that the EASD had given financial support to the Pancreatic Islet Study Group. The Metabolism and Insulin Action. Study Group had not taken advantage of this offer. 


\section{Any other business}

The President asked the General Assembly for approval of the new Associate and Supporting membership fees. From 1995 onwards the fees will be divided into three categories, Gold $£ 2,500$, Silver $-£ 1,000$ and Associate $-£ 500$. The General Assembly unanimously approved these new fees.

Dr. Alberti informed the members that in relation with the new joint activities with the JDFI, Dr. P. Halban had been appointed as EASD/JDFI Liaison Officer.
At the end of the General Assembly, a complaint was received regarding the allocation of the hall for the Islet Group which did not provide sufficient seating. Dr. de Leiva apologized and explained that rooms are allocated according to topics. It was promised to ensure allocation of an adequate hall in 1995.

After having thanked the retiring Vice-President, Dr. C.B.Wollheim and the retiring Council Members, Drs. N.Bagriacik, J.E.Campillo and U.Fischer, the President closed the General Assembly.

Table 1. Consolidated accounts for the year ended 31 December 1993

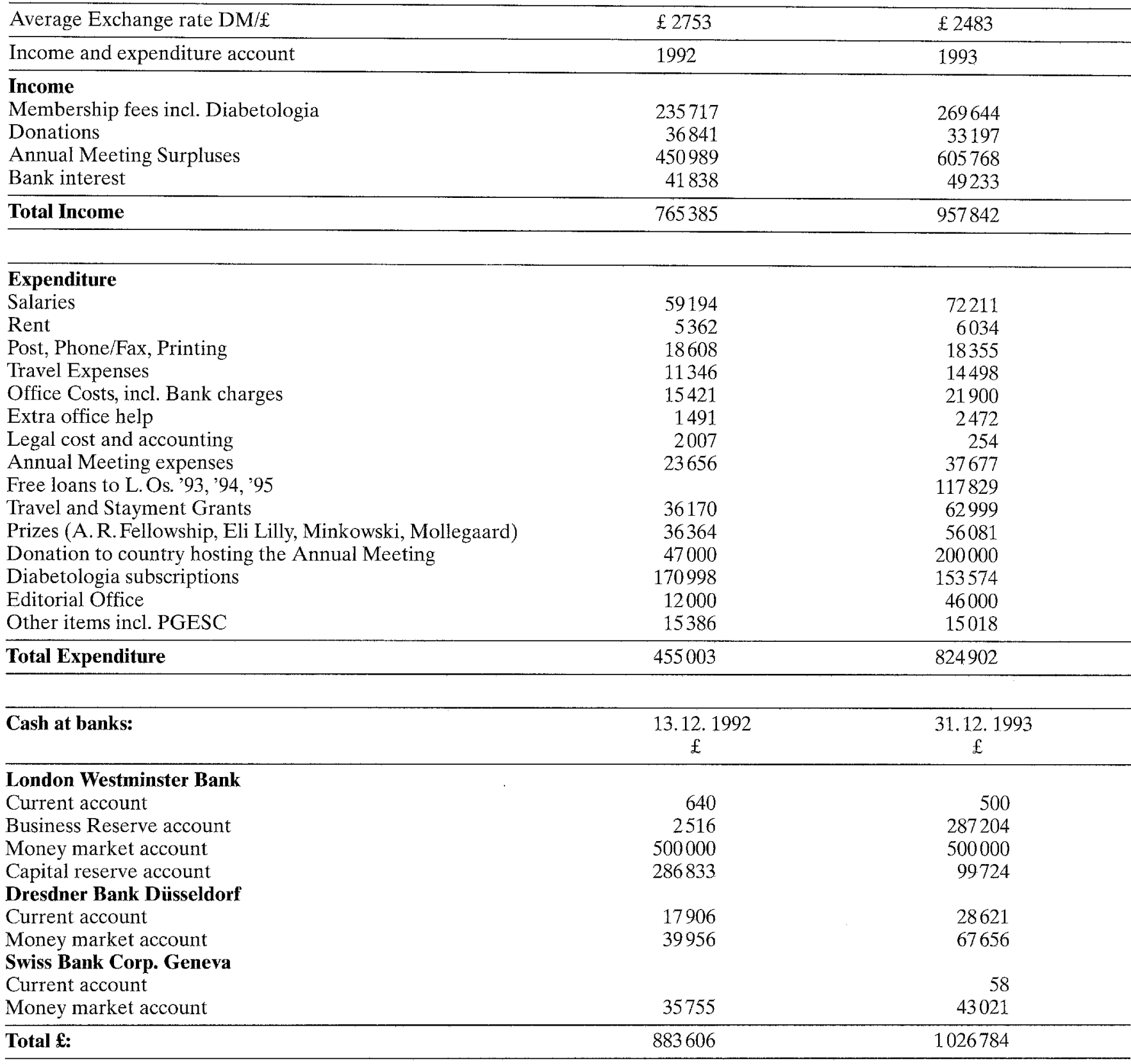

Year end exchange rates:

1992: $£$-DM 2.753 SFr-DM 111.19

1993: $£$-DM 2.556 SFr-DM 117.64 
Table 2. Future EASD Annual Meetings

\begin{tabular}{lcl}
\hline 1995 & $12-16$ September & Stockholm, Sweden \\
1996 & $2-5$ September & Vienna, Austria \\
1997 & $20-25$ July, IDF Meeting & Helsinki, Finland \\
1998 & & Barcelona, Spain \\
1999 & & Brussels, Belgium \\
2000 & & Jerusalem, Israel \\
\hline
\end{tabular}

Table 3. Breakdown of membership by country compared to previous years (as of 31st December):

\begin{tabular}{|c|c|c|c|c|c|c|}
\hline & 1993 & 1992 & 1991 & 1990 & 1989 & 1988 \\
\hline Albania & - & - & 1 & 1 & - & - \\
\hline Algeria & 4 & 1 & - & 1 & 1 & - \\
\hline Argentina & 7 & 6 & 6 & 6 & 8 & 8 \\
\hline Australia & 66 & 61 & 54 & 52 & 48 & 42 \\
\hline Austria & 54 & 57 & 37 & 34 & 39 & 34 \\
\hline Bahrain & 0 & 2 & 2 & 1 & 1 & 1 \\
\hline Bangladesh & 3 & 3 & 1 & 1 & 1 & 1 \\
\hline Belgium & 154 & 161 & 140 & 138 & 140 & 111 \\
\hline Brazil & 10 & 9 & 9 & 9 & 9 & 4 \\
\hline Bulgaria & 59 & 36 & 32 & 24 & 19 & 16 \\
\hline Cameroon & 1 & 1 & - & - & - & - \\
\hline Byelorussia & 1 & - & 1 & - & - & - \\
\hline Canada & 36 & 32 & 33 & 33 & 35 & 26 \\
\hline Ceylon & 1 & 1 & 1 & - & - & - \\
\hline Chile & 3 & 3 & 4 & 4 & 4 & 3 \\
\hline China & 1 & 1 & 2 & 2 & 2 & 1 \\
\hline Colombia & 1 & 1 & - & 1 & 1 & 1 \\
\hline Costa Rica & - & 1 & 1 & 1 & 1 & - \\
\hline Cuba & 1 & - & - & - & 1 & 1 \\
\hline Croatia & 25 & 22 & 25 & - & - & - \\
\hline Cyprus & 8 & 8 & 8 & 10 & 6 & 5 \\
\hline Czech Rep. & 44 & 45 & 70 & 68 & 52 & 46 \\
\hline Denmark & 273 & 266 & 256 & 267 & 206 & 212 \\
\hline Dominican Rep. & 1 & 1 & - & 1 & 1 & 1 \\
\hline Egypt & 11 & 12 & 12 & 13 & 9 & 8 \\
\hline Estonia & 7 & 6 & 5 & - & - & - \\
\hline Ethiopia & - & - & 1 & 1 & - & - \\
\hline Finland & 93 & 100 & 95 & 97 & 87 & 68 \\
\hline France & 217 & 218 & 222 & 252 & 254 & 237 \\
\hline Georgia & 2 & 1 & 1 & - & - & - \\
\hline Germany & 363 & 350 & 315 & 319 & 262 & 220 \\
\hline Greece & 126 & 125 & 131 & 118 & 122 & 82 \\
\hline Hungary & 58 & 56 & 48 & 42 & 41 & 34 \\
\hline Iceland & 1 & 1 & 2 & 2 & 2 & 2 \\
\hline India & 8 & 9 & 6 & 7 & 8 & 6 \\
\hline Indonesia & 1 & 1 & 1 & - & 2 & - \\
\hline Iran & 1 & 1 & - & - & - & - \\
\hline Ireland & 29 & 34 & 38 & 22 & 14 & 13 \\
\hline Israel & 48 & 35 & 40 & 45 & 45 & 36 \\
\hline Italy & 422 & 454 & 427 & 390 & 317 & 284 \\
\hline Jamaica & - & 1 & 1 & 1 & 1 & - \\
\hline Japan & 76 & 62 & 52 & 49 & 40 & 32 \\
\hline Kazahkstan & 3 & 3 & 1 & - & - & - \\
\hline Kenya & - & - & - & - & 1 & - \\
\hline South Korea & 6 & 6 & 3 & 11 & 4 & 4 \\
\hline Kuwait & 3 & 3 & 4 & 5 & 4 & 3 \\
\hline Latvia & 1 & 1 & - & - & - & - \\
\hline Lebanon & 1 & 1 & 1 & 1 & 1 & 1 \\
\hline Libya & - & - & - & - & 1 & - \\
\hline Lithuania & 10 & 9 & 9 & - & - & - \\
\hline Luxembourg & 3 & 3 & 2 & 2 & 1 & 1 \\
\hline
\end{tabular}

\begin{tabular}{|c|c|c|c|c|c|c|}
\hline & 1993 & 1992 & 1991 & 1990 & 1989 & 1988 \\
\hline Macao & 1 & 1 & - & - & - & - \\
\hline Macedonia & 7 & 2 & - & - & - & - \\
\hline Malta & 4 & - & - & - & - & - \\
\hline Malaysia & - & 1 & 3 & 6 & 3 & 2 \\
\hline Mexico & 3 & 3 & 3 & 2 & 2 & 1 \\
\hline Moldavia & - & -. & 1 & - & - & - \\
\hline Morocco & 2 & 2 & 3 & 3 & 3 & 1 \\
\hline Netherlands & 213 & 180 & 151 & 150 & 141 & 123 \\
\hline New Zealand & 10 & 10 & 11 & 7 & 5 & 5 \\
\hline Norway & 105 & 76 & 68 & 72 & 62 & 56 \\
\hline Oman & 1 & 1 & 1 & 1 & 1 & - \\
\hline Pakistan & 3 & 2 & 2 & 2 & 1 & - \\
\hline Paraguay & 1 & 1 & 1 & 1 & 1 & 1 \\
\hline Peru & - & 1 & 1 & 2 & 2 & - \\
\hline Philippines & 1 & 1 & 2 & 3 & - & - \\
\hline Poland & 80 & 63 & 56 & 42 & 31 & 21 \\
\hline Portugal & 105 & 55 & 57 & 54 & 53 & 40 \\
\hline Qatar & - & - & - & 1 & 1 & 1 \\
\hline Romania & 44 & 38 & 59 & 49 & 47 & 41 \\
\hline Russia & 37 & 35 & 30 & - & - & - \\
\hline Saudi Arabia & 17 & 19 & 9 & 8 & 9 & 10 \\
\hline Singapore & 3 & 3 & 4 & 4 & - & - \\
\hline Slovakia & 20 & - & - & - & - & - \\
\hline Slovenia & 21 & 13 & 7 & - & - & - \\
\hline S. Africa & 27 & 35 & 27 & 29 & 10 & 8 \\
\hline Spain & 162 & 152 & 131 & 122 & 109 & 96 \\
\hline Sudan & 1 & 1 & 1 & 1 & 1 & - \\
\hline Sweden & 310 & 337 & 270 & 253 & 265 & 219 \\
\hline Switzerland & 86 & 85 & 104 & 110 & 110 & 101 \\
\hline Tahiti & 1 & - & - & - & - & - \\
\hline Taiwan & 12 & 8 & 7 & 6 & 4 & 3 \\
\hline Tanzania & 2 & 1 & - & 1 & 1 & 1 \\
\hline Tatarstan & 1 & 1 & - & - & - & - \\
\hline Thailand & 4 & 4 & 3 & 3 & 3 & 2 \\
\hline Tonga & 1 & 1 & - & - & - & - \\
\hline Tunisia & 1 & 1 & 1 & - & - & 1 \\
\hline Turkey & 32 & 21 & 13 & 11 & 11 & 9 \\
\hline Ukraine & 16 & 14 & 10 & -. & - & - \\
\hline United Emirates & 3 & 1 & 2 & 2 & 1 & 1 \\
\hline United Kingdom & 404 & 396 & 495 & 420 & 404 & 404 \\
\hline USA & 232 & 209 & 199 & 169 & 165 & 164 \\
\hline USSR & - & - & - & 36 & 22 & 13 \\
\hline Uzbekistan & 1 & 1 & 1 & 1 & 1 & 1 \\
\hline Yugoslavia & - & 15 & 18 & 37 & 30 & 9 \\
\hline Zaire & - & - & - & 1 & - & - \\
\hline Zimbabwe & 1 & 1 & 1 & 1 & 1 & 1 \\
\hline
\end{tabular}

Table 4. Figures for membership at the end of 1993 compared to previous years:

As of 31st December

19931992199119901989198819871986198519841983 $42444000384736453317291823172181 \quad 18391901 \quad 1677$ 